\title{
Lactational responses to postruminal infusions of amino acids in dairy cows fed maize silage, hay or grass silage
}

\author{
L Le Henaff, $H$ Rulquin, R Vérité
}

Station de Recherches sur la Vache Laitière, INRA, Saint-Gilles, 35590 L'Hermitage, France

Duodenal infusions of methionine and lysine have been shown to increase milk protein yield in dairy cows given a dehydrated maize diet (Rulquin, 1987). As duodenal amino acids (AA) profiles vary according to diet (Le Henaff, unpublished), a trial was undertaken to test the lactational responses of dairy cows to methionine and lysine infusions with 3 other diets based on either maize silage $(M)$, perennial ryegrass hay $(H)$ or silage $(S)$.

Each diet was given to a different group of 6 fistulated Holstein cows in early lactation that received duodenal infusions of either $11 \mathrm{~g}$ of methionine and $24 \mathrm{~g}$ of lysine (ML) or $90 \mathrm{~g}$ of glutamic acid (control) in a double reversal design over 2 wk periods. Diets were calculated to be isoenergetic either with 'fibrous' concentrate $(26 \%$ of the diet $M$ ) or a 'starchy' concentrate (43.6\% of the diet $\mathrm{H}$ and $28 \%$ of the diet S) and to supply in theory the same level of intestinal digestible proteins in order to meet $90 \%$ of the protein requirement.

The ML infusion significantly increased milk yield only with diet $M(+3.9 \%)$ and protein yield with diets $M(+8.8 \%)$ and $S$ $(+3.7 \%)$ (table I). The protein content was significantly increased by $\mathrm{ML}$ with diets $\mathrm{M}$ $(+4.8 \%)$ and $\mathrm{H}(+2 \%)$ and casein content with diet $M$. The $M L$ infusion decreased the fat content with diet $M$. These results, consistent with those of Schwab et al (1976) and of Rulquin (1987), indicate that methionine and lysine are not as clearly limiting factors with hay and grass silage as with maize silage diets.

Acknowledgments - Rhône Poulenc Animal Nutrition for funding this research.

Rulquin H (1987) Reprod Nutr Dév 27, 229-230 Schwab CG, Satter LD, Clay AB (1976) J Dairy Sci $59,1254-1270$

Table I. Effect of ML on lactating cows fed 3 different diets.

\begin{tabular}{|c|c|c|c|c|c|c|}
\hline & \multicolumn{2}{|c|}{ Maize silage } & \multicolumn{2}{|c|}{ Hay } & \multicolumn{2}{|c|}{ Grass silage } \\
\hline & control & $M L$ & control & $M L$ & control & $M L$ \\
\hline $\begin{array}{l}\text { Milk yield }(\mathrm{kg} / \mathrm{d}) \\
\text { Protein }(\mathrm{g} / \mathrm{kg}) \\
\text { Fat }(\mathrm{g} / \mathrm{kg}) \\
\text { Casein } \mathrm{g} / \mathrm{kg})\end{array}$ & $\begin{array}{l}30.4 \\
28.0 \\
40.5 \\
23.3\end{array}$ & $\begin{array}{l}31.6^{*} \\
29.4^{\text {** }} \\
38.9^{*} \\
24.7^{\text {** }}\end{array}$ & $\begin{array}{l}27.9 \\
28.9 \\
36.2 \\
24.3\end{array}$ & $\begin{array}{l}28.2 \\
29.5 * \\
36.5 \\
24.8\end{array}$ & $\begin{array}{l}29.5 \\
27.8 \\
34.3 \\
23.5\end{array}$ & $\begin{array}{l}30.2 \\
28.0 \\
34.2 \\
23.8\end{array}$ \\
\hline
\end{tabular}

ML : methionine lysine; within a diet: ${ }^{*} P<0.05 ;{ }^{* *} P<0.01$. 